\title{
KEDUDUKAN DAN TUGAS PENDIDIK DALAM PENDIDIKAN ISLAM
}

\author{
Moh. Asnawi*
}

\begin{abstract}
Abstrak
Pendidik merupakan kunci keberhasilan pendidikan, sehingga pendidik memiliki kedudukan yang sangat penting. Untuk menjadi pendidik ada prasyarat yang harus dipenuhinya. Disamping pendidik memiliki kemampuan dalam bidang akadenik, pendidik juga dituntut memiliki akhlak yang terpuji, baik dihadapan murid maupun dihadapat masyarakat. Dengan demikian pendidik disamping bertugas sebagai orang yang mentrasfer pengetahuan ia pun bertugas dalam mentrasfer nilai-nilai positif kepada peserta didik. Dalam mencapai tugasnya tersebut seorang pendidik harus dapat menjadi panutan baik di sekolah maupun di masyarakat. Tanpa keteladanan yang dimilikinya tugas dalam melakukan proses trasformasi ilmu dan nilai tidak dapat berjalan dengan baik.
\end{abstract}

Kata Kunci: kedudukan, tugas, pendidik dan pendidikan Islam

\section{Pendahuluan}

Dalam Undang-undang RI Nomor 20 Tahun 2003 tentang Sistem Pendidikan Nasional, Bab I Pasal 1 butir 5 ditetapkan bahwa Tenaga Kependidikan adalah anggota masyarakat yang mengabdikan diri dan diangkat untuk menunjang penyelenggaraan pendidikan. Dan butir 6 ditetapkan bahwa Pendidik adalah tenaga kependidikan yang berkualifikasi sebagai guru, dosen, konselor, pamong belajar, Widyaiswara, tutor, instruktur, fasilitator, dan sebutan lain yang sesuai dengan

* Institut Agama Islam Tribakti (IAIT) Kediri 
kekhususannya, serta berpartisipasi dalam menyelenggarakan pendidikan.

Di Jepang pendidik dipanggil Sensei adalah suatu profesi profesional yang paling terhormat, paling mulia, penentu masa depan bangsa, dan sangat didambakan oleh masyarakat Jepang, tetapi hanya sebagian kecil yang dapat meraihnya, karena hanya yang memiliki prestasi akademik yang tinggi dan yang betulbetul berbakat menjadi pendidik berdasarkan hasil tes bakat, serta sehat jasmani dan rohani saja yang dapat diterima menjadi calon pendidik di perguruan tinggi (Lembaga Pendidikan Tenaga Kependidikan). Hanya 2 (dua) profesi di Jepang dipanggil Sensei yaitu: pendidik' dan 'dokter'. Pendidik di Indonesia, walaupun diakui juga sebagai profesi profesional yang terhormat, paling mulia, strategis, dan penentu masa depan bangsa, tetapi tetap merupakan profesi kerdil, melarat, dan kurang diminati, karena kurang menjanjikan masa depan yang cemerlang. Baru setelah adanya sertifikasi guru, posisinya menjadi lebih baik dalam dimensi profesi maupun ekonomi.

Kondisi kehidupan global yang semakin kompetitif menuntut tersedianya sumber daya manusia (SDM) yang berkualitas. Dalam konteks pengembangan SDM melalui pendidikan. Pendidik memegang peranan dan posisi kunci. Pendidik merupakan masukan instrumental yang paling berpengaruh terhadap terciptanya proses dan mutu pendidikan yang berkualitas. Upaya perbaikan apa pun yang dilakukan untuk meningkatkan mutu pendidikan tidak akan banyak berarti tanpa dukungan pendidik yang berkualitas.

Kualitas pendidikan memiliki ketergantungan pada banyak faktor misalnya: guru, kurikulum, sarana prasarana, biaya, sistem pengelolaan, iklim kerja dan siswa sendiri. Di antara sekian banyak faktor, pendidik dinilai memiliki peran kunci dalam pencapaian kualitas. Hampir semua usaha reformasi pendidikan seperti pembaharuan kurikulum dan penerapan metode pembelajaran baru akhirnya tergantung pada pendidik. Tanpa mereka pengusaan materi pelajaran, strategi pembelajaran, memotivasi siswa untuk belajar sungguh-sungguh dalam mencapai prestasi, maka segala upaya yang dilakukan untuk meningkatkan kualitas pendidikan tidak akan mencapai 
hasil maksimal. ${ }^{1}$ Pendidik merupakan kunci keberhasilan proses pembelajaran. Semua komponen dalam proses pembelajaran materi, media, sarana, dana pendidikan tidak akan memberikan dukungan yang maksimal tanpa didukung keberadaan pendidik. ${ }^{2}$

Hasil studi yang dilakukan oleh Heyneman dan Loxly dalam Supriadi yang dilakukan di 29 negara menunjukan bahwa di anatara berbagai masukan yang menentuakan pendidikan (prestasi siswa), lebih dari sepertiganya ditentukan oleh pendidik. Peran guru makin lebih penting lagih di tengah keterbatasan sarana dan prasarana sebagaimana dialami negarnegara berkembang dan anak-anak kurang beruntung yang tinggal di lingkungan kurang menunjang bagi proses belajarnya. Menurut hasil studi tersebut di 16 negara yang sedang berkembang (India, Mesir, Bosnia, Thailand, Chile, el Savador, Kolombia, Meksiko, Brazil, Argentina, Peru, Uganda, Honggaria, Paraguy, Iran dan Bolivia) pendidik memberikan kontribusi terhadap prestasi peserta belajar sebesar $34 \%$, sedangkan manajemen $22 \%$, waktu belajar $18 \%$, dan sarana fisik $26 \%$. Di 13 Negara Industri (Amerika Serikat, Inggris, Skotlandia, Belanda, Jerman, Swedia, Belgia yang meliputi tiga kelompok etnis, Selandia Baru, Australia, Itali dan Jepang), kontribusi pendidik $36 \%$, manajemen $23 \%$, waktu belajar 22 $\%$, dan sarana fisik $19 \%{ }^{3} \quad$ Dari hasil studi tersebut, salah satu yang perlu mendapatkan prioritas dalam mengatasi masalah pendidikan adalah peningkatan mutu pendidik, karena dengan kualitas pendidik yang baik akan mengarah tercitanya pendidikan yang baik pula.

Berbagai upaya pengembangan ke arah itu, telah banyak dilakukan. Namun demikian dalam prosesnya masih banyak kendala. Masih ada sebagian masyarakat yang menganggap bahwa pendidik merupakan suatu pekerjaan yang dapat dilakukan oleh siapa saja tanpa melalui pendidikan khusus. Di samping itu, sarana prasarana, kurikulum dan dana penunjang

1 Desi Supriadi, Mengangkat Citra dan Martabat Guru, (Yogyakarta: Adicipta Arya Nusa, 1999), h. 178

${ }^{2}$ Ibrahaim Bafadal, Supervisi Pendidikan: Teori dan Aplikasinya dalam Membina Profesionalisme Guru, (Jakarta: Bumi Aksara, 2003), h. 31..

${ }^{3}$ Mengambil dari Desi Supriadi, Mengangkat Citra dan, h. 178 
kegiatan pendidikan masih sangat rendah/kurang. Untuk menciptakan Sumber Daya Manusia (SDM) yang berkualitas dan mampu bersaing dengan SDM dari negara maju di dunia ini, maka pendidik merupakan penentu utama dalam keberhasilan pendidikan. Dan keberhasilan pendidikan akan berdampak sangat luas bagi kehidupan berbangsa dan bernegara. Dari aspek kualitas pendidik ada komponen penting yang harus dimiliki oleh pendidik, yakni bagaimana kedudukan dan tugas pendidik dalam pendidikan Islam? Sebagai ungkapan yang sederhana dan mudah namun memiliki makna yang sangat luas.

\section{Pendidik dalam Konteks Pendidikan Islam}

Dalam konteks pendidikan Islam "pendidik" sering disebut dengan murabbi, mu'allim, mu'addib, mudarris, dan mursyid. Menurut peristilahan yang dipakai dalam pendidikan dalam konteks Islam, kelima istilah ini mempunyai tempat tersendiri dan mempunyai tugas masing-masing.

Murabbi adalah orang yang mendidik dan menyiapkan peserta didik agar mampu berkreasi serta mampu mengatur dan memelihara hasil kreasinya untuk tidak menimbulkan malapetaka bagi dirinya, masyarakat dan alam sekitarnya. Mu'allim adalah orang yang menguasai ilmu dan mampu mengembangkannya sertam menjelaskan fungsinya dalam kehidupan, menjelaskan dimensi teoritis dan praktisnya, sekaligus melakukan transfer ilmu pengetahuan, internalisasi serta implementasi. Mu'addib adalah orang yang mampu menyiapkan peserta didik untuk bertanggungjawab dalam membangun peradaban yang berkualitas di masa depan. Mudarris adalah orang yang memiliki kepekaan intelektual dan informasi serta memperbaharui pengetahuan dan keahliannya secara berkelanjutan, dan berusaha mencerdaskan peserta didiknya, memberantas kebodohan mereka, serta melatih keterampilan sesuai dengan bakat, minat dan kemampuannya. Mursyid adalah orang yang mampu menjadi model atau sentral identifikasi diri atau menjadi pusat anutan, teladan dan konsultan bagi peserta didiknya.

Sebagaimana teori Barat, pendidik dalam Islam adalah orang-orang yang bertanggung jawab terhadap perkembangan peserta didiknya dengan upaya mengembangkan seluruh potensi 
peserta didik, baik potensi afektif (rasa), kognitif (cipta), maupun psikomotorik (karsa). ${ }^{4}$ Pendidik berarti juga orang dewasa yang bertanggung jawab memberi pertolongan pada peserta didiknya dalam perkembangan jasmani dan rohaninya, agar mencapai tingkat kedewasaan, mampu berdiri sendiri dan memenuhi tingkat kedewasaannya, mampu mandiri dalam memenuhi tugasnya sebagai hamba dan khalifah Allah SWT. Dan mampu melaksanakan tugas sebagai makhluk sosial dan sebagai makhluk individu yang mandiri. ${ }^{5}$ Pendidik menjadi orang yang mempersiapkan dan mengatarkan anak didiknya agar bahagia di dunia dan di akhiratnya.

Pendidik pertama dan utama adalah orang tua sendiri. Mereka berdua yang bertanggung jawab penuh atas kemajuan perkembangan anak kandungnya, karena sukses tidaknya anak sangat tergantung kepada pengasuhan, perhatian, dan pendidikannya. Kesuksesan anak kandung merupakan cermin atas kusuksesan orang tua juga. Firman Allah SWT. "Peliharalah dirimu dan keluargamu dari api neraka". 6

Pendidik di sini adalah mereka yang memberikan pelajaran kepada peserta didik, yang memegang suatu mata pelajaran tertentu di sekolah. ${ }^{7}$ Orang tua sebagai pendidik pertama dan utama terhadap anak-anaknya, tidak selamanya memiliki waktu yang leluasa dalam mendidik anak-anaknya. Selain karena kesibukan kerja, tingkat efektifitas dan efisiensi pendidikan tidak akan baik jika pendidikan hanya dikelola secara alamiah. Oleh karena itu, anak lazimnya dimasukkan ke dalam lembaga pendidikan (sekolah/madrasah). Penyerahan peserta didik ke lembaga (sekolah/madrasah) bukan berarti melepaskan tanggung jawab orang tua sebagai pendidik yang pertama dan utama, tetapi orang tua tetap mempunyai saham yang besar dalam membina dan mendidik anak kandungnya. Lembaga pendidikan berkedudukan sebagai estafet orang tua, karena berbagai keterbatasan yang dimilikinya. Di samping itu

\footnotetext{
${ }^{4}$ Ahmad Tafsir, Ilmu Pendidikan dalam Perspektif Islam, (Bandung: Remaja Rosdakarya, 1992), h. 74-75.

${ }^{5}$ Suryosubrata B., Beberapa Aspek Dasar Kependidikan, (Jakarta: Bina Aksara, 1983), h.26

${ }^{6}$ QS. At-Tahrim: 6

${ }^{7}$ Ahmad Tafsir, Ilmu Pendidikan dalam, h. 75
} 
tuntutan dan perkembangan zaman tidak memungkinkan semua orang tua dapat mejalankan tanggung jawab mendidik sampai batas usia dewasa (18 tahun) pada semua bidang disiplin ilmu yang menjadi kebutuhan anak di masa depan. Namun yang menjadi catatan penting bahwa peran serta orang tua dalam hal mendidik anak tidak pernah putus dan berhenti, dalam memberikan bimbingan dan mengarahkan pentingnya arti kehidupan. Ada banyak tokoh, menjadikan orang tuanya sebagai sumber inspirasi atas keberhasilannya.

\section{Syarat Pendidik dalam Pendidikan Islam}

Syaikh Ahmad Ar Rifai mengungkapkan, bahwa seseorang bisa dianggap sah untuk dijadikan sebagai pendidik dalam pendidikan Islam apabila memenuhi dua kriteria berikut: pertama, alim yaitu mengetahui betul tentang segala ajaran dan syariahnya Nabi Muhammad Saw, sehingga ia akan mampu mentransformasikan ilmu yang komprehensif tidak setengahsetengah. Keduan, adil riwayat yaitu tidak pernah mengerjakan satu pun dosa besar dan mengekalkan dosa kecil, seorang pendidik tidak boleh fasik sebab pendidik tidak hanya bertugas mentransformasikan ilmu kepada anak dididiknya namun juga pendidik harus mampu menjadi contoh dan suri tauladan bagi seluruh peserta didiknya. Di khawatirkan ketika seorang pendidik adalah orang fasik atau orang bodoh, maka bukan hidayah yang diterima anak didik namun justru pemahamanpemahaman yang keliru yang berujung pada kesesatan. ${ }^{8}$

Menurut Ibnu Sina pendidik yang baik adalah pendidik yang berakal cerdas, beragama, mengetahui cara mendidik akhlak, cakap dalam mendidik anak, berpenampilan tenang, jauh dari berolok-olok dan main-main dihadapan muridnya, tidak bermuka masam, sopan santun, bersih dan suci murni. Selain itu, pendidik harus mengutamakan kepentingan umat, dari pada kepentingan dirinya sendiri, menghidari dari orang-orang yang berakhlak rendah, mengetahui etika dalam majelis ilmu, sopan dan santun dalam berdebat, berdiskusi dan bergaul. ${ }^{9}$

\footnotetext{
${ }^{8}$ Ahmad Ar Rifa'I, Takhyirah Mukhtashor, (tk., tp., tt), h.10

${ }^{9}$ Ibnu Sina, As-Siyasah fi at Tarbiyah, (Mesir: Majalah Al Masyrik, 1906), h. 1076.
} 
Menurut al Ghazali, syarat menjadi seorang pendidik pertama, kasih saying. Sifat ini dinilai penting karena akan menimbulkan rasa percaya diri dan rasa tenang pada diri murid. Kedua, seorang pendidik tidak boleh menuntut upah atas jeri payahnya mendidik. Ketiga, pendidik berfungsi sebagai pengarah dan penyuluh yang jujur dan benar dihadapan muridnya. Keempat, ketika mengajar seorang pendidik hendaknya menggunakan cara yang simpatik, halus dan tidak menggunakan kekerasan, cacian, makian dan sebagainya. Kelima, seorang pendidik yang baik tampil sebagai teladan dihadapan murid-muridnya. Keenam, seorang pendidik yang baik juga harus memiliki prinsip mengakui adanya perbedaan potensi yang dimuliki murid. Ketujuh, seorang pendidik yang baik memahami perbedaan kecerdasan muridnya. Kedelapan, seorang pendidik yang baik adalah pendidik yang berpegang teguh pada prinsip yang diucapkannya. ${ }^{10}$

Dalam hal ini, ketika syarat seorang pendidik dapat terpenuhi seperti tersebut di atas, maka kedudukan pendidik menjadi tinggi di mata anak didik. Para murid harus menunjukan hormat dan kepatuhan mutlak kepada gurunya, bukan sebagai manifestasi dari penyerahan total kepada pendidik yang dianggap memiliki otoritas, tetapi karena keyakinan murid kepada kedudukan pendidik sebagai penyalur kemurahan Tuhan yang dilimpahkan kepada murid-muridnya, baik di dunia maupun di akhirat. ${ }^{11}$ Menurut ajaran Islam, si murid harus menganggap gurunya seolah-olah sebagai ayahnya sendiri sebagaimana dikatakan dalam hadits: "Ayahmu itu sebenarnya ada tiga. Pertama, bapakmu yang telah membuahi ibumu; kedua, bapak yang telah memberimu seorang istri; dan ketiga, guru yang sedang dan telah mengajarmu". "Dan sesungguhnyalah, orang yang mengajarmu walau pun hanya sepatah kata dalam pengetahuan agama adalah ayahmu menurut ajaran Islam". ${ }^{12}$

${ }^{10}$ Al Ghazali, Ihya Ulumu ad Din, juz I, h. 51..

Zamakhsyari Dhofier, Tradisi Pesantren: Studi Tentang Pandangan Hidup Kyai, (Jakarta: LP3ES, 1994), h. 61.

${ }^{12}$ Zarnuji, Ta'lim Al-Muta'allim, (Kudus: Menara 1963), h. 63-65. 


\section{Kedudukan Pendidik dalam Pendidikan Islam}

Pendidik adalah spiritual father (bapak rohani), bagi peserta didik yang memberikan santapan jiwa dengan ilmu, pembinaan akhlak mulia, dan meluruskan perilakunya yang buruk. Oleh karena itu, pendidik memiliki kedudukan tinggi. Dalam beberapa Hadits disebutkan: "Jadilah engkau sebagai guru, atau pelajar atau pendengar atau pecinta, dan Janganlah engkau menjadi orang yang kelima, sehingga engkau menjadi rusak".. Bahkan Islam menempatkan pendidik setingkat dengan derajat seorang Rasul. Al-Syawki bersyair: "Berdiri dan hormatilah guru dan berilah penghargaan, seorang guru itu hampir saja merupakan seorang Rasul", 13

Al-Ghazali menukil beberapa Hadits Nabi tentang keutamaan seorang pendidik. Ia berkesimpulan bahwa pendidik disebut sebagai orang-orang besar yang aktivitasnya lebih baik daripada ibadah setahun, ${ }^{14}$ selanjutnya Al-Ghazali menukil dari perkataan para ulama yang menyatakan bahwa pendidik merupakan pelita segala zaman, orang yang hidup semasa dengannya akan memperoleh pancaran cahaya keilmiahannya. Andai kata dunia tidak ada pendidik, niscaya manusia seperti binatang, sebab: pendidikan adalah upaya mengeluarkan manusia dari sifat kebinatangan (baik binatang buas maupun binatang jinak ${ }^{15}$ kepada sifat insaniyah dan ilahiyah. ${ }^{16}$

Kedudukan seorang guru menjadi penerang dalam kehidupan di dunia terlebih di akherat. Dalam konteks

13 M. Athiyah al-Abrasyi, Dasar-dasr Pokok Pendidikan Islam, terj..Bustami A. Ghani, (Jakarta: Bulan Bintang, 1987), h. 135-136

${ }^{14}$ Perhatikan QS. At-Taubah:122

${ }^{15}$ Binatang buas (subu'iyah) menurut al-Ghazali sebagai natur dasar struktur al-ghadhab adalah suatu daya yang berpotensi untuk menghindari diri dari segala yang membahayakan, dengan cara menyerang, membunuh, merusak, menyakiti, dan membuat yang lain menderita. Sedangkan binatang jinak (bahimiyyah) merupakan natur dasar struktur al-syahwat, yaitu suatu daya yang berpotensi untuk menginduksi diri dari segala yang menyenangkan. Syahwat merupakan potensi hawa nafsu yang memiliki natur atau naluri dasar seks bebas, erotisme, narsisme, dan segala tindakan untuk pemuasan birahi. Lebih lanjut baca: Abdul Mujib, Kepribadian dalam Psikologi Islam, (Jakarta: Rajawali Press, 2006), h. 109-110.

${ }^{16}$ Abu Hamid Muhammad al-Ghazali, Ihya 'ulum al-Din, terj. Ismail ya'qub, (Semarang: Faizan, 1979), h. 65, 68, 70. 
pendidikan Islam kedudukan guru sedemikan sangat penting, seperti yang diuraikan oleh Dhofier:

Hubungan tradisi pesantren, perasaan hormat dan kepatuhan murid kepada gurunya adalah mutlak dan tidak boleh putus, artinya berlaku seumur hidup si murid. Di samping itu rasa hormatnya yang mutlak itu harus ditunjukkan dalam seluruh aspek kehidupannya, baik dalam kehidupan keagamaan, kemasyarakatan, maupun pribadi. Melupakan ikatan dengan guru dianggap sebagai suatu aib besar, di samping akan menghilangkan barakah guru. Akibat selanjutnya dari kehilangan berkah guru ialah pengetahuan si murid tidak akan bermanfaat. Umpamanya, kalau kemudian ia memimpin sebuah pesantren, ia tidak akan dapat menarik santri yang banyak, atau akan kalah sukses dibandingkan teman-teman seangkatannya yang tidak melupakan hubungannya dengan guru. Bagi seorang santri adalah "tabu" mengatakan bahwa ia "bekas" murid dari seorang kyai tertentu, sebab sekali ia menjadi murid kyai tersebut, seumur hidupnya akan tetap menjadi muridnya. Bahkan bilamana guru tersebut telah meninggal, si murid masih harus menunjukan hormatnya dengan tidak melupakan kontak dengan pesantren sang guru. Demikian pula ia juga harus menghormati anak gurunya. Kyai Tahrir dari Susukan, Salatiga, yang sekarang ini berumur \pm 70 tahun, selalu pergi kepesantren Watucongol, Muntilan Magelang untuk mengikuti pengajian bulanan yang diberikan oleh Kyai Hamid, putra kyai Dalhar, gurunya dalam tafsir dan figh semasa berada di Watucongol antara tahun 1927-1932.

Dalam kitab Ta'lim Al-Muta'allim tertulis ajaran berikut: "Mereka yang mencari pengetahuan hendaklah selalu ingat bahwa mereka tidak akan pernah mendapatkan pengetahuan atau pengetahuannya tidak akan berguna, kecuali kalau ia menaruh hormat kepada guru yang mengajarkannya. Hormat kepada guru bukan hanya sekedar patuh." Sebagaimana dikatakan oleh Sayidina 'Ali, "Saya ini hamba dari orang yang mengajar saya, walaupun hanya satu kata saja". ${ }^{18}$

${ }^{17}$ Zamakhsyari Dhofier, Tradisi Pesantren: Studi Tentang Pandangan Hidup Kyai, (Jakarta: LP3ES, 1994), h. 61.

${ }^{18}$ Zarnuji, Ta'lim Al-Muta'allim, (Kudus: Menara 1963), h. 60. 
Kedudukan guru dalam seluruh kehidupan si murid demikian pentingnya, sehingga seorang murid harus mempertimbangkan betul-betul sebelum memutuskan untuk belajar dengan seorang guru tertentu. Dalam Ta'lim AlMuta'allim dijelaskan agar menimbang-nimbang guru yang akan dipilihnya, paling tidak selama 2 bulan sehingga ia yakin bahwa guru tersebut adalah orang yang betul-betul alim dan arif, orang yang selalu menahan diri dari perbuatan-perbuatan, baik yang dilarang, dimakruhkan maupun belum jelas diperkenankan oleh agama (dalam kalangan pesantren orang seperti ini disebut wira'i); dan guru tersebut harus seorang yang sudah penuh pengalaman untuk menjadi guru (asann). Di samping itu juga disarankan agar seorang calon murid mencari keterangan dan meminta nasihat dari orang-orang yang pernah belajar dengan guru tersebut, ${ }^{19}$ dan tidak meninggalkan gurunya sebelum ia menyelesaikan mata pelajaran yang ia tuntut, sebab bila demikian ia tidak akan memperoleh manfaat atau berhasil dalam studinya (fala yubaraku fit ta'allumi). ${ }^{20}$

Kepatuhan mutlak seorang murid kepada guru tidak berarti bahwa murid tersebut harus mengikuti perintah gurunya yang bertentangan dengan ajaran Islam. Dalam Ta'allim tertulis: "Janganlah kamu patuh kepada seseorang yang tingkah lakunya tidak sesuai dengan ajaran Islam". ${ }^{21}$

Dalam tradisi Pesantren, sekali seorang guru melakukan perbuatan maksiat, maka guru tersebut tidak lagi dianggap sebagai penyalur barakah dan kemurahan Tuhan. Perlu ditekankan di sini, bahwa hormat dan kepatuhan absolut kepada seorang guru didasari kepercayaan bahwa guru tersebut memiliki kesucian karena memegang kunci penyalur pengetahuan dari Allah. Bila guru tersebut melakukan perbuatan yang dilarang oleh agama, maka tingkat kesucian itu akan hilang. Oleh karena itu, menurut ajaran Islam, kewajiban seorang murid untuk patuh secara mutlak kepada gurunya harus kita mengerti dalam hubungan kesalehan guru kepada Allah swt, ketulusannya, kerendahan hatinya, dan kecintaannya mengajar

\footnotetext{
${ }^{19}$ Ibid., h. 45-47.

${ }^{20}$ Ibid.,h. 50-52

${ }^{21}$ Ibid., 65.
} 
murid-muridnya. Kepercayaan murid kepada guru didasarkan kepada kepercayaan bahwa gurunya adalah seorang alim yang terpilih. Di samping itu para guru mencurahkan waktu dan tenaganya mengajar murid-muridnya karena si guru merasa bertanggung Jawab di depan Allah untuk menyalurkan ilmu yang dimilikinya kepada muridnya. Kesaling-tergantungan antara guru dan murid, kesaling-pengertian mereka, ketulusan bersama, kesabaran, ketulusan dan kecintaan antara guru dan murid, semuanya merupakan faktor yang sebenarnya menjamin kelangsungan kehidupan pesantren.

\section{Tugas Pendidik dalam Pendidikan Islam}

Menurut al-Ghazali, tugas pendidik yang utama adalah menyempurnakan, membersihkan, menyucikan, serta membawakan hati manusia untuk mendekatkan diri kepada Allah SWT. Karena tujuan pendidikan Islam yang utama adalah upaya untuk mendekatkan diri kepada-Nya, dan kesempurnaan insan yang bermuara pada kebahagiaan di dunia dan di akhirat.

Dalam paradigma Jawa, pendidik diidentikan dengan ( $g u$ dan $r u$ ) yang berarti "digugu dan ditiru”. Dikatakan digugu (dipercaya) karena guru mempunyai seperangkat ilmu yang memadai, yang karenanya ia memiliki wawasan dan pandangan yang luas dalam melihat kehidupan ini. Dikatakan ditiru (di ikuti) karena guru mempunyai kepribadian yang utuh, yang karenanya segala tindak tanduknya patut dijadikan panutan dan suri tauladan oleh peserta didiknya.

Seorang pendidik bukanlah bertugas memindahkan atau mentrasfer ilmunya kepada orang lain atau kepada anak didiknya. Tetapi pendidik juga bertanggung jawab atas pengelolaan, pengarah fasilitator dan perencanaan. Oleh karena itu, fungsi dan tugas pendidik dalam pendidikan dapat disimpulkan menjadi tiga bagian, yaitu:

1. Sebagai instruksional (pengajar), yang bertugas merencanakan program pengajaran dan melaksanakan program yang telah disusun serta mengakhiri dengan pelaksanaan penilaian setelah program dilakukan.

2. Sebagai educator (pendidik), yang mengarahkan peserta didik pada tingkat kedewasaan dan berkepribadian kamil seiring dengan tujuan Allah SWT menciptakannya. 
3. Sebagai managerial (pemimpin), yang memimpin, mengendalikan kepada diri sendiri, peserta didik dan masyarakat yang terkait, terhadap berbagai masalah yang menyangkut upaya pengarahan, pengawasan, pengorganisasian, pengontrolan dan partisipasi atas program pendidikan yang dilakukan. ${ }^{22}$

Dalam tugas itu, seorang pendidik dituntut untuk mempunyai seperangkat prinsip keguruan. Prinsip keguruan itu dapat berupa:

1. Kegairahan dan kesediaan untuk mengajar seperti memerhatikan: kesediaan, kemampuan, pertumbuhan dan perbedaan peserta didik.

2. Membangkitkan gairah peserta didik

3. Menumbuhkan bakat dan sikap peserta didik yang baik

4. Mengatur proses belajar mengajar yang baik

5. Memerhatikan perubahan-perubahankecendrungan yang mempengaruhi proses mengajar

6. Adanya hubungan manusiawi dalam proses belajar mengajar.

Mendidik lebih bersifat kegiatan berkerangka jangka menengah atau jangka panjang. Hasil pendidikan tidak dapat dilihat dalam waktu dekat atau secara instan. Pendidikan merupakan kegiatan integratif olah pikir, olah rasa, dan olah karsa yang bersinergi dengan perkembangan tingkat penalaran peserta didik.

Mendidik bobotnya adalah pembentukan sikap mental/kepribadian bagi anak didik, sedang mengajar bobotnya adalah penguasaan pengetahuan, keterampilan dan keahlian tertentu yang berlangsung bagi semua manusia pada semua usia. Contoh seorang guru matematika mengajarkan kepada anak pintar menghitung, tapi anak tersebut tidak penuh perhitungan dalam segala tindakannya.

Tidak setiap guru mampu mendidik walau pun ia pandai mengajar, untuk menjadi pendidik guru tidak cukup menguasai materi dan keterampilan mengajar saja, tetapi perlu memahami dasar-dasar agama dan norma-norma dalam masyarakat,

${ }^{22}$ Roestiyah NK, Masalah-masalah Ilmu Keguruan, (Jakarta: Bina Aksara, 1982), h. 86. 
sehingga guru dalam pembelajaran mampu menghubungkan materi yang disampaikannya dengan sikap dan keperibadiaan yang harus tumbuh sesuai dengan ajaran agama dan normanorma dalam masyarakat. Jadi, jika hasil pengajaran dapat dilihat dalam waktu singkat atau paling lama tiga tahun, keluaran pendidikan tidak dapat dilihat sebagai satu hasil yang segmentatif. Hasil pendidikan tercermin dalam sikap, sifat, perilaku, tindakan, gaya menalar, gaya merespons, dan corak pengambilan keputusan peserta didik atas suatu.

Menurut Abuddin Nata, secara sederhana tugas pendidik adalah mengarahkan dan membimbing para murid agar semakin meningkat pengetahuannya, semakin mahir keterampilannya dan semakin terbina dan berkembang potensinya. Sedangkan tugas pokok pendidik adalah mendidik dan mengajar. Mendidik ternyata tidak semudah mengajar. ${ }^{23}$ Dalam proses pembelajaran pendidik harus mampu mengilhami peserta didik melalui proses belajar mengajar yang dilakukan pendidik sehingga mampu memotivasi peserta didik mengemukakan gagasan-gagasan yang besar dari peserta didik.

Dalam konteks mengajar, pendidik mesti menyadari bahwa setiap mata pelajaran mestinya membawa dan mengandung unsur pendidikan dan pengajaran. Unsur pendidikan, dimaknai dapat membina dan menempa karakter pendidik agar berjiwa jujur, bekerja secara cermat dan sistematik. Sedangkan unsur pengajaran dimaknai untuk

${ }^{23}$ Abuddin Nata, Paradigma Pendidikan Islam, (Jakarta: Grasindo, 2001), h. 134. Pada bagian lain Abuddin Nata, Manajemen Pendidikan: Mengatasi Kelemahan Pendidikan Islam di Indonesia, (Bogor, Kencana, 2003), h. 145-146 mendefenisikan mengajar dengan penciptaan sistem lingkungan yang memungkinkan proses belajar mengajar. Sistem lingkungan ini terdiri dari komponen-komponen yang saling mempengaruhi, yakni tujuan instruksional (kompetensi dasar) yang ingin dicapai, materi yang akan diajarkan, pendidik dan peserta didik yang harus memainkan peranan serta ada dalam hubungan sosial tertentu, jenis kegiatan yang dilakukan, serta sarana dan prasarana belajar mengajar yang tersedia. Di samping itu, menurut Al-Syaibany, dalam mengajar, pendidik harus mengetahui dasar-dasar umum metode mengajar. Paling tidak menurut Al-Syaibani dasar umum itu adalah dasar agama dan dasar bio-psikologis. Lihat Omar Mohammad Al-Toumy Al-Syaibany, Falsafatut Tarbiyah Al-Islamiyah, terj. Hasan Langgulung, Falsafah Pendidikan Islam, (Jakarta: Bulan Bintang, 1979), h. 586-591. 
memberikan pemahaman kepada peserta didik kepada setiap mata pelajaran yang diterimanya.

Secara khusus, bila dilihat tugas guru pendidikan agama (Islam) adalah di samping harus dapat memberikan pemahaman yang benar tentang ajaran agama, juga diharapkan dapat membangun jiwa dan karakter keberagamaan yang dibangun melalui pengajaran agama tersebut. Artinya tugas pokok guru agama menurut Abuddin Nata adalah menanamkan ideologi Islam yang sesunggunya pada jiwa anak. ${ }^{24}$

Pada uraian yang lebih jelas Abuddin Nata lebih merinci bahwa tugas pokok guru (pendidik) adalah mengajar dan mendidik. Mengajar disini mengacu kepada pemberian pengetahuan (transfer of knowledge) dan melatih keterampilan dalam melakukan sesuatu, sedangkan mendidik mengacu pada upaya membina kepribadian dan karakter si anak dengan nilainilai tertentu, sehingga nilai-nilai tersebut mewarnai kehidupannya dalam bentuk perilaku dan pola hidup sebagai manusia yang berakhlak.

Apabila pendidik dilihat dalam konteks yang luas, maka tugas pendidik bukan hanya di sekolah (madrasah) tetapi dapat juga melaksanakan tugasnya di rumah tangga. Menurut Ahmad Tafsir, ${ }^{25}$ tugas mendidik di rumah tangga dapat dilaksanakan dengan muda, karena Tuhan (Allah) telah menciptakan landasannya, yaitu adanya rasa cinta orang tua terhadap anaknya yang merupakan salah satu dari fitrahnya. Rasa cinta terlihat misalnya dalam Qur'an surat al-Kahfi ayat 46 dan surat alFurqan ayat 74. Cinta kepada anak-anak telah diajarkan juga oleh Rasulullah kepada para sahabat. Seorang Baduwi datang

${ }^{24}$ Abuddin Nata, Paradigma, h. 135. Menanamkan ideologi Islam ini, Abuddin Nata, mengutip pendapat Muhammad S.A. Ibrahimmy, sarjana pendidikan Islam Bangladesh — , dimana menurut Ibrahimmy, pendidikan Islam dalam pengertian sebenarnya adalah suatu sistem pendidikan yang menginginkan seseorang dapat mengarahkan kehidupannya sesuai dengan cita-cita Islam, sehingga ia dengan mudah dapat membentuk kehidupan dirinya sesuai dengan ajaran Islam. Ruang lingkup pendidikan Islam harus mengalami perubahan menurut tuntutan zaman dan perkembangan ilmu pengetahuan dan teknologi. Ruang lingkup pendidikan Islam itu juga makin luas.

${ }_{25}$ Ahmad Tafsir, Metodologi Pengajaran Agama Islam, (Bandung: Remaja Rosdakarya, 2000), cet.ke-5, h. 135-136 
kepada Muhammad saw. dan bertanya, "Apakah engkau menciumi putra-putri engkau? Kami tidak pernah menciumi anak-anak kami." Orang yang mulia itu berkata, "Apakah kamu tidak takut Allah akan mencabut kasih sayang dari hatimu? (H.R Bukhari).

Ramayulis, menguraikan tugas pendidik sebagai warasat al-anbiya (pewaris nabi), pada hakekatnya mengemban misi rahmat li al-'alamin yakni suatu misi yang mengajak manusia untuk tunduk dan patuh pada hukum-hukum Allah, guna memperoleh keselamatan dunia dan akhirat. Untuk melaksanakan tugas demikian, pendidik harus bertitik tolak pada amar ma'ruf nahi mungkar, menjadikan prinsip tauhid sebagai pusat kegiatan penyebaran misi iman, islam dan ihsan, kekuatan yang dikembangkan oleh pendidik adalah individualitas, sosial dan moral. ${ }^{26}$ Muh. Uzer Usman, menjelaskan bahwa tugas guru (pendidik) sebagai profesi meliputi mendidik, mengajar dan melatih. Mendidik berarti meneruskan dan mengembangkan nilai-nilai hidup. Mengajar berati meneruskan dan mengembangkan ilmu pengetahuan dan teknologi. Sedangkan melatih berarti mengembangkan keterampilan-keterampilan pada siswa. ${ }^{27}$

${ }^{26}$ Dalam uraiannya tentang tugas pendidik, Ramayulis menyamakan antara tugas pendidik dengan peranan pendidik. Dalam kaitan ini penulis cenderung membedakan antara tugas pendidik dengan peranan pendidik.

${ }^{27}$ Muh. Uzer Usman, Menjadi Guru Profesional, (Bandung: Remaja Rosdakarya, 2003), h. 7. Lihat juga, Muhaimin, Pengembangan... op.cit., (Jakarta: RajaGrafindo Persada, 2005), h. 50. Dalam uraiannya Muhaimin menjelaskan bahwa tugas mendidik, mengajar dan melatih dalam konteks pendidikan nasional. Dalam konteks pendidikan Islam, karakteristik ustadz selalu tercermin dalam segala aktifitasnya sebagai murabby, mu'allim, mursyid, mudarris, dan mu'addib. Pernyataan yang sama dikemukan oleh Syaiful Bahri Djamarah, Guru dan Anak Didik dalam Interaksi Edukatif, Jakarta: Rineka Cipta, 2000, h. 37. Dalam uraiannya, Djamarah menjelaskan tugas guru (pendidik) sebagai suatu profesi menuntut kepada guru untuk mengembangkan profesionalitas diri sesuai perkembangan ilmu pengetahuan dan teknologi. Mendidik, mengajar dan meltih anak didik adalah tugas guru sebagai suatu profesi. Tugas guru sebagai pendidik berarti meneruskan dan mengembangkan nilai-nilai hidup kepada anak didik. Tugas guru sebagai pengajar berarti meneruskan dan mengembangkan ilmu pengetahuan dan teknologi kepada anak didik. Tugas guru sebagai pelatih berarti mengembangkan keterampilan dan menerapkannya dalam kehidupan demi 
Pada bagian lain, Usman menyoroti tugas guru dalam bidang kemanusiaan di sekolah harus dapat menjadikan dirinya sebagai orang tua kedua. Ia harus mampu menarik simpati sehingga ia menjadi idola para siswanya. Pelajaran apapun yang diberikan hendaknya dapat motivasi bagi siswanya dalam belajar.

Sedangkan tugas guru pada bagian lain adalah terhadap kehidupan bermasyarakat, berbangsa dan bernegara. Pada bidang ini guru merupakan komponen strategis yang memilih peran yang penting dalam menentukan gerak maju kehidupan bangsa. ${ }^{28}$

\section{Simpulan}

Mendidik yang dikatakan oleh sebagian orang sebagai pranata yang dapat menjalankan tiga fungi sekaligus. Pertama, mempersiapkan generasi muda untuk untuk memegang perananperanan tertentu pada masa mendatang. Kedua, mentransfer pengetahuan, sesuai dengan peranan yang diharapkan. Ketiga, mentransfer nilai-nilai dalam rangka memelihara keutuhan dan kesatuan masyarakat sebagai prasyarat bagi kelangsungan hidup masyarakat dan peradaban. Butir kedua dan ketiga di atas memberikan pengerian bahwa mendidik bukan hanya transfer of knowledge tetapi juga transfer of value. Dengan demikian

masa depan anak didik. Tugas kemanusiaan salah satu segi dari tugas guru, karena guru harus terlibat dengan khidupan di masyarakat dengan interaksi sosial. Guru harus menanamkan nilai-nilai kemanusiaan kepada anak didik. Guru harus dapat menempatkan diri sebagai orang tua kedua, dengan mengemban tugas yang dipercayakan orang tua kandung/wali anak didik dalam jangka waktu tertentu. Di bidang kemasyarakatan guru mempunyai tugas mendidik dan mengajar masyarakat untuk menjadi warga negara Indonesia yang bermoral Pancasila.

28 Ibid. Lihat juga Abuddin Nata, Manajemen Pendidikan: Mengatasi Kelemahan Pendidikan Islam di Indonesia, (Bogor, Kencana, 2003), h. 142-143. Dalam uraiannya Nata menjelaskan ciri-ciri profesionalisme pendidik adalah: pertama, harus menguasai bidang ilmu pengetahuan yang akan diajarkannya dengan baik. Kedua, harus memiliki kemampuan menyampaikan atau mengajarkan ilmu yang dimilikinya (transfer of knowledge) kepada murid-muridnya dengan efektif dan efisien . Ketiga, harus berpegang teguh kepada kode etik profesional yakni memiliki akhlak yang mulia. 
pendidikan dapat menjadi penolong bagi umat manusia. Sementara mengajar hanya pada tataran transfer of knowledge.

Keteladanan adalah sikap terpuji yang semestinya melekat pada semua pendidik. Jadi, dengan demikian, setiap pendidik seharusnya menjadi model untuk mendorong pembentukan sikap terpuji peserta didik. Disinilah tugas pendidik bukan sekadar mengajar yang sangat teknis, melainkan mendidik untuk membentuk insan generasi muda yang berperilaku mulia, baik, jujur serta mampu mengembangkan potensi yang dimiliki oleh siswa didiknya.

\section{Daftar Pustaka}

Ar Rifa'I, Ahmad, Takhyirah Mukhtashor, Tanpa Tahun.

al-Ghazali, Abu Hamid Muhammad, Ihya 'Ulum Al-Din, terj. Ismail ya'qub, Semarang: Faizan, 1979.

al-Abrasyi, M. Athiyah, Dasar-dasr Pokok Pendidikan Islam, terj..Bustami A. Ghani, Jakarta: Bulan Bintang, 1987.

Bafadal, Ibrahaim, Supervisi Pendidikan: Teori dan Aplikasinya dalam Membina Profesionalisme Guru, Jakarta: Bumi Aksara, 2003.

Dhofier, Zamakhsyari, Tradisi Pesantren: Studi Tentang Pandangan Hidup Kyai, Jakarta: LP3ES, 1994.

Tafsir, Ahmad, Ilmu Pendidikan dalam Perspektif Islam, Bandung: Remaja Rosdakarya, 1992.

Mujib, Abdul, Kepribadian dalam Psikologi Islam, Jakarta: Rajawali Press, 2006.

Roestiyah, NK, Masalah-masalah Ilmu Keguruan, Jakarta: Bina Aksara, 1982.

Sina, Ibnu, As-Siyasah fi at Tarbiyah, Mesir: Majalah Al Masyrik, 1906.

Supriadi, Desi, Mengangkat Citra dan Martabat Guru, Yogyakarta: Adicipta Arya Nusa, 1999.

Suryosubrata, B., Beberapa Aspek Dasar Kependidikan, Jakarta: Bina Aksara, 1983.

Zarnuji, Ta'lim Al-Muta'allim, Kudus: Menara 1963. 